и управление. - 2016. - Т. 5. - № 3 (16). - С. 183-188.

8. Хлесткина, Е.К. Маркер-ориентированная селекция и примеры ее использования в мировом картофелеводстве / Е.К. Хлесткина, В.К. Шумный, Н.А. Колчанов // Достижения науки и техники АПК. - 2016. - Т. 30. - № 10. - С. 96-103.

9. Чесноков, Ю.В. Генетические ресурсы растений и ускорение селекционного процесса / Ю.В. Чесноков, В.М. Косолапов. - М.: ООО «Угрешская типография», 2016. $-172 \mathrm{c}$.

DOI 10.18699/GPB2020-93

\title{
Влияние погодных условий на продолжительность вегетационного периода и урожайность сортов пшеницы в лесостепи Приобья
}

Лихенко И.Е. ${ }^{1,2}$, д.с.-х.н., зам. директора, рук. СибНИИРС - филиала ИЦиГ СО РАН; Капко T.H. ${ }^{2}$, м.н.с.; Агеева E.B. ${ }^{2}$, к.с.-х.н., н.с.; Советов B.B. ${ }^{2}$, к.с.X.H., C.H.C.

${ }^{1}$ Институт цитологии и генетики СО РАН, Новосибирск, Россия;

${ }^{2}$ Сибирский научно-исследовательский институт растениеводства и селекичи - филиал ИЦиГ СО РАН, п. Краснообск, Новосибирская обл., Россия. e-mail:sibniirs@bk.ru

В статье представлены результаты изучения зависимости величины урожайности пшенищы разных групп спелости от тепло- и влагообеспеченности за период вегетаџии. Установлено, что в условиях недостатка тепла и влаги большую значимость для производства имеют раннеспелье и среднеранние сорта по сравнению со среднепоздними.

Ключевые слова: пшеница, группа спелости, подбор сортов.

\section{The influence of weather conditions on the length of vegetation period and the crop yields of bread wheat varieties in the forest steppe of the $\mathrm{Ob}$ region}

Likhenko I.E. ${ }^{1,2}$, Kapko T.N. ${ }^{2}$, Ageeva E.V. ${ }^{2}$, Sovetov V.V. ${ }^{2}$.

${ }^{l}$ Institute of Cytology and Genetics, Siberian Branch of Russian Academy of Sciences, Novosibirsk, Russia;

${ }^{2}$ Siberian Research Institute of Plant Production and Breeding - Branch of the Institute of Cytology and Genetics, Siberian Branch of the Russian Academy of Sciences, Krasnoobsk, Novosibirsk region, Russia.

E-mail: sibniirs@bk.ru

The paper presents the results of study of the dependence of the yield of wheat of different ripeness groups on the heat and moisture supply during the growing season. It is established that in conditions of lack of heat and moisture, early ripen-ing and mid-early varieties are of great importance for production in comparison with medium-late ones.

Key words: wheat, ripeness group, selection of varieties. 
Продолжительность вегетационного периода в значительной степени зависит от погодных условий. Еще в первой половине прошлого века [1] установлено, что потребность растения в температуре и влаге не одинакова в течение жизненного цикла. Для пшеницы особенно выделяется фаза колошения, когда происходят существенные изменения в отношении потребности к условиям произрастания. Известно, что с ростом среднесуточных температур воздуха в периоды от всходов до колошения и от колошения до восковой спелости продолжительность вегетационного периода яровой пшеницы сокращается [2].

Правильный выбор сортов, оптимально приспособленных к климатическим особенностям местности - это важнейшая задача для производителя зерна, особенно в суровых условиях Западной Сибири. В частности, климат Новосибирской области отличается короткой весной с ночными заморозками до конца мая, коротким жарким летом с нестабильными осадками и периодическими засухами, а также ранней осенью с неустойчивой погодой и ранними заморозками. Также для этой территории типичны моросящие дожди, часто (особенно осенью) продолжающиеся по нескольку дней и затрудняющие уборку [3].

В настоящее время в Новосибирской области районировано 29 сортов мягкой яровой пшеницы, в том числе 11 (38 \%) - раннеспелой и среднеранней групп спелости. По данным Россельхозцентра, в области всего высевается (по данным 2018 г.) 64 сорта мягкой яровой пшеницы, и, если смотреть по объему высеянных семян, наиболее популярными являются раннеспелые и среднеранние сорта (высеяно $55 \%$ от общего объема сортовых семян).

Целью исследования является обоснование подбора сортов мягкой яровой пшеницы раннеспелой и среднеранней групп спелости, адекватно соотносящихся с климатическими условиями Новосибирской области.

Исследования проводились с 2008 по 2018 гг. на опытном поле лаборатории селекции, семеноводства и технологии возделывания полевых культур СибНИИРС - филиала ИЦиГ СО РАН в условиях лесостепи Приобья Новосибирской области. Анализ климатических изменений на территории по данным метеостанции «Огурцово» за годы изучения свидетельствует о нестабильности тепло- и влагообеспеченности как по годам, так и в течение вегетационного периода. В этот период в большинстве лет наблюдалась июньская засуха. Условия вегетации 2008, 2010, 2012, 2016 гг. по метеорологическим показателям (ГТК) характеризовались как засушливые; 2009, 2011 и 2014 гг. - как умеренно увлажненные, а 2013, 2015, 2017 и 2018 гг. как переувлажненные. За этот период отмечено 4 прохладных года с наиболее продолжительным вегетационным периодом (2009, 2010, 2013 и 2018 гг.), что объясняется умеренным накоплением необходимой суммы эффективных температур, тогда как 2011, 2012, 2015-2017 гг. отмечаются как наиболее теплообеспеченные. 
В качестве модельных были выбраны 3 года (рисунок): 2012 (как наиболее засушливый и жаркий), 2013 (как наиболее увлажненный и прохладный) и 2018 (поскольку в этот год темпы накопления эффективных температур были максимально приближены к среднему многолетнему значению, а распределение осадков за вегетацию было достаточным для оптимального формирования урожая пшеницы, даже в типично засушливый для местности период - в начале июня).

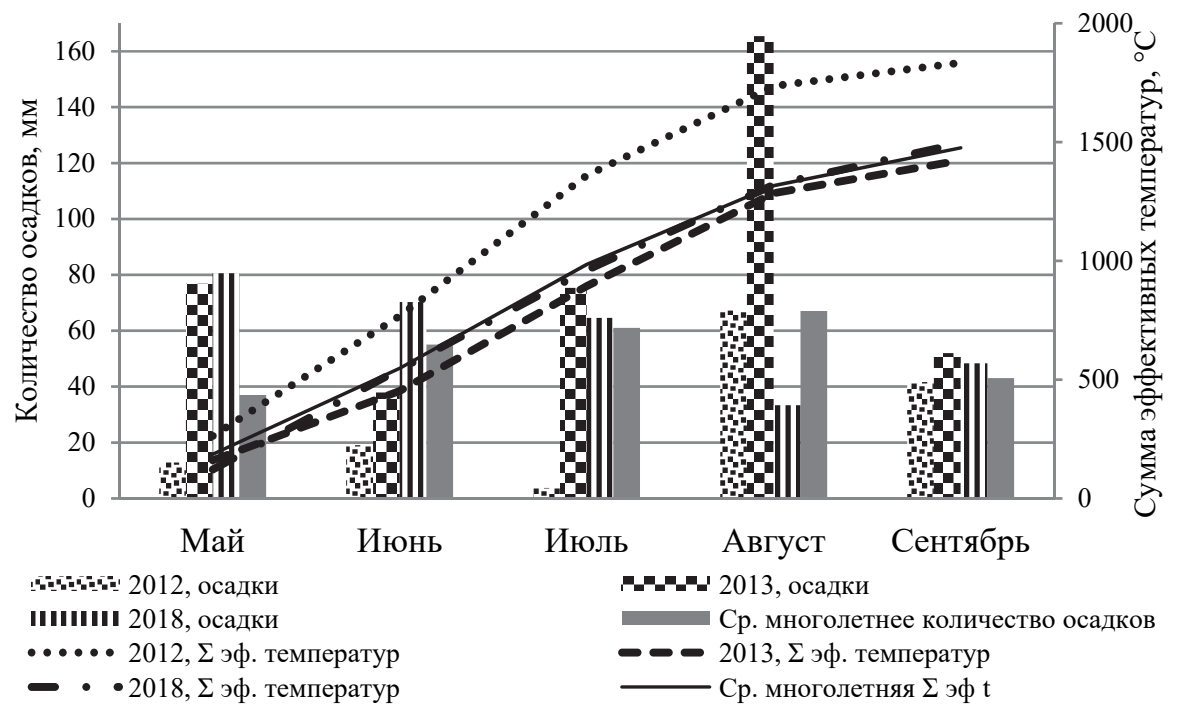

Рисунок. Темпы накопления суммы эффективных температур и количество осадков, выпавших за вегетационный период 2012, 2013, 2018 гг. (по данным ГМС Огурцово): осадки - количество осадков за период, мм; Бэф.t - сумма эффективных температур, ${ }^{\circ} \mathrm{C}$.

Для изучения было отобрано 7 сортов сибирской селекции разных групп спелости - от раннеспелой до среднепоздней (таблица). Известно, что при нормальных сроках посева и благоприятных условиях развития суммы эффективных температур, необходимые для созревания, практически постоянны для каждого сорта [4]. С поправкой на микроклиматические особенности территории, потребность раннеспелых сортов в тепле от всходов до созревания составляет $1000^{\circ} \mathrm{C}$, среднеранних $-1100^{\circ} \mathrm{C}$, среднеспелых $1200^{\circ} \mathrm{C}$, среднепоздних $-1300^{\circ} \mathrm{C}$ и позднеспелых $-1400^{\circ} \mathrm{C}$ [5]. По данным ГМС Огурцово, среднее многолетнее значение суммы эффективных температур на конец сентября составляет $1476^{\circ} \mathrm{C}$, причем, эта величина рассчитывается не от всходов, а с момента перехода среднесуточной температуры воздуха через $5{ }^{\circ} \mathrm{C}$. Это говорит о том, что возделывание позднеспелых сортов в лесостепи Новосибирской области довольно рискованно. 
Таблица - Зависимость урожайности пшеницы от тепло- и влагообеспеченности за период вегетации в зависимости от группы спелости (п. Краснообск, 2012, 2013, 2018 гг.)

\begin{tabular}{|c|c|c|c|c|c|c|c|c|c|c|}
\hline \multirow[b]{2}{*}{ Сорт } & \multirow[b]{2}{*}{ 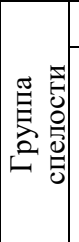 } & \multicolumn{3}{|c|}{2012 г. } & \multicolumn{3}{|c|}{2013 г. } & \multicolumn{3}{|c|}{2018 г. } \\
\hline & & $\begin{array}{l}\text { U } \\
0 \\
\text { 言 } \\
\text { W. }\end{array}$ & 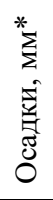 & 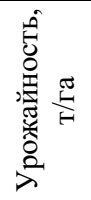 & $\begin{array}{l}\text { O } \\
\text { 言 } \\
\text { 离 }\end{array}$ & 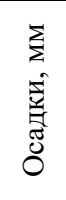 & 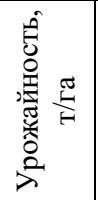 & $\begin{array}{l}0 \\
0 \\
\text { 言 } \\
\text { W. }\end{array}$ & 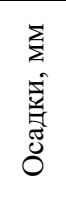 & 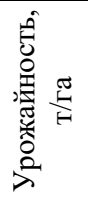 \\
\hline Новосибирская 15 & $\mathrm{P} / \mathrm{C}$ & 935 & 24 & 1,55 & 952 & 242 & 1,44 & 1023 & 139 & 3,53 \\
\hline Новосибирская 29 & $\mathrm{C} / \mathrm{P}$ & 1042 & 24 & 1,53 & 1061 & 274 & 1,40 & 1054 & 151 & 3,66 \\
\hline Новосибирская 31 & $\mathrm{C} / \mathrm{P}$ & 1094 & 24 & 1,59 & 1098 & 274 & 1,52 & 1099 & 187 & 3,90 \\
\hline Новосибирская 18 & $\mathrm{C} / \mathrm{C}$ & 1119 & 24 & $2,16^{* *}$ & 1098 & 274 & $1,64 * *$ & 1122 & 187 & 4,78 \\
\hline Новосибирская 44 & $\mathrm{C} / \mathrm{C}$ & 1100 & 24 & 1,60 & 1150 & 282 & 1,41 & 1089 & 187 & 4,48 \\
\hline Омская 37 & $\mathrm{C} / \Pi$ & 1199 & 24 & 1,72 & 1150 & 282 & 1,40 & - & - & - \\
\hline Обская 2 & $\mathrm{C} / \Pi$ & - & - & - & - & - & - & 1166 & 201 & $5,56 * *$ \\
\hline Ср. урожайность & & & & 1,69 & & & 1,47 & & & 4,32 \\
\hline $\mathrm{HCP}_{05}$ & & 132 & 0 & 0,36 & 110 & 22 & 0,14 & 75 & 37 & 1,16 \\
\hline
\end{tabular}

*сумма эффективных температур от всходов до созревания;

** отклонение от среднего значения статистически значимо.

Если тепла хватает для вызревания среднепоздних сортов даже в прохладные годы, как, например, 2013, то количество осадков практически ежегодно выступает в качестве ограничивающего фактора. В целом сибирские территории отличаются большим разнообразием природно-климатических условий. Некоторые провинции отличаются друг от друга по величине гидротермического коэффициента в разы. Обращает на себя внимание, что в засушливом 2012 г. за всю вегетацию от всходов и до уборки выпало всего 24 мм осадков - только в мае и июне, тогда как июль был жаркий, сухой, и за весь месяц зарегистрировано выпадение только 4 мм. Урожайность изучаемых сортов достоверно не отличалась от среднего значения (только у сорта Новосибирская 18 она была выше). В условиях избыточного увлажнения и недостатка тепла 2013 года отмечена та же закономерность - не установлено достоверных отклонений по урожайности от среднего значения (только у сорта Новосибирская 18 она была выше). Причем, можно отметить тенденцию к снижению урожайности в 2013 году относительно 2012, что говорит о том, что отрицательное влияние избытка влаги при низких температурах воздуха на урожайность проявляется в большей степени, нежели воздействие избытка тепла при недостаточной влагообеспеченности. В благоприятном 2018 г. наблюдается тенденция увеличения урожайности в зависимости от увеличения срока созревания, но только у среднепозднего сорта Обская 2 урожайность достоверно превысила среднее значение. 
Что касается неконтролируемых природных условий, следует отметить общеизвестный факт о существенном ухудшении качества зерна при неблагоприятных погодных условиях. Это дожди, а также чередование дождей и засушливых периодов непосредственно в период и/или перед уборкой. В связи с этим стоит констатировать, что чем раньше наступает момент созревания и, соответственно, уборки, тем больше шансов получить высококачественное зерно. Таким образом, мы подходим к единственно верному решению проблемы - необходимости правильно подобрать сорт с оптимальной продолжительностью вегетационного периода, адекватно соотносящейся с климатическими условиями территории, на которой осуществляется производство.

В заключение, хотелось бы отметить, что при благоприятных погодных условиях сорта пшеницы среднепоздней группы спелости способны давать наиболее высокий урожай высокий урожай по сравнению с сортами других групп спелости. Но в связи с тем, что основным лимитирующим фактором при формировании урожайности в условиях Новосибирской области является количество осадков, потенциал этих сортов в полной мере реализуется только в благоприятные годы. В этом отношении сорта других групп спелости в засушливые и избыточно увлажненные годы не уступают им по урожайности, а в ряде случаев и превосходят их (как, например, среднеспелый сорт Новосибирская 18). Поэтому, учитывая климатические особенности территории, при подборе сортимента особое внимание стоит обратить на засухоустойчивые сорта среднеспелой группы. В свою очередь, раннеспелые и среднеранние сорта вне зависимости от условий вегетации способны обеспечивать урожайность на уровне среднего значения.

Благодарности: Работа выполнена при поддержке бюджетного проекта ИЦиГ СО РАН № 0324-2019-0039-С-01.

\section{Список литературь}

1. Ацци Дж. Сельскохозяйственная экология / пер. с англ. Н.А. Емельяновой и др.; под ред. В.Е. Писарева. М.: Изд-во Иностранной литературы, 1959. 479 с.

2. Коряковцева А.А., Сафина Н.З. Сопряженность продолжительности вегетационного периода и урожайности сортов яровой пшеницы двух групп спелости с метеорологическими условиями // Аграрная наука Евро-Северо-Востока. 2006. № 8. С. 19-22.

3. Воронина Л.В. Климат и экология Новосибирской области: монография / Л.В. Воронина, А.Г. Гриценко. Новосибирск: СГГА, 2011. 228 с.

4. Серякова Л.П. Метеорологические условия и растения (учебное пособие по агрометеорологии) / ред. Ю.П. Андрейков. Л.: Типография ВВМУП им. Лен. комсомола, $1971.77 \mathrm{c}$.

5. Шашко Д.И. Агроклиматическое районирование СССР. М: Колос, 1967. 336 с. 